DOI: 10.1515/ausp-2016-0018

\title{
An Evergreen Challenge for Translators - The Translation of Idioms
}

\author{
Gabriella KOVÁCS \\ Sapientia Hungarian University of Transylvania (Târgu-Mureş, Romania) \\ Department of Applied Linguistics \\ kovagabi@yahoo.com
}

\begin{abstract}
Translating idioms has always been a challenging decision-making process for translators mainly because not all idioms have direct equivalents in the target language. Translators usually and ideally have a solid knowledge of the target language and its cultural aspects, but even so they cannot match the ability of a native speaker in deciding when - i.e. in what context and text type - an idiom would or would not be appropriate. This study aims to explore the main characteristics of idioms and the difficulties which might occur when translating them. A needs analysis will also be presented, where the various solutions which a group of translator trainees chose while translating certain idioms from the novel "A Game of Thrones" by George R. R. Martin into Hungarian are examined. Their strategies and the appropriateness of their choices are analysed and compared with the options of the experienced literary translator (Tamás Pétersz). We consider this an important endeavour because, based on our experience, we believe that the topic of the translation of idioms should be included into the curriculum and appropriate materials and tasks should be designed to develop the translator trainees' knowledge and skills in this domain. Therefore, the aim of this analysis is to obtain a clearer view of the difficulties they are dealing with and bear them in mind when designing teaching materials for them.
\end{abstract}

Keywords: translation of idioms, translator trainees, translation strategies, difficulties

\section{Introduction}

Translating idioms has always been a challenging decision-making process for translators. Even experienced and acknowledged translators, who usually and ideally have a solid knowledge of the target language and its cultural aspects, cannot match the ability of a native speaker in deciding when - meaning, in what context and text type - an idiom would or would not be appropriate. Besides a thorough knowledge of the source and target language, this process indispensably 
requires creativity and the skill, willingness, and perseverance to search for the best equivalent. Along their studies and the subsequent years of experience, translators usually develop - consciously or instinctively - different strategies and solutions regarding the translation of idioms.

Another significant factor contributing to efficient translations would be that translators should ideally translate into their native language and not into a second language. It is well known that they possess a more profound knowledge of the linguistic and cultural aspects of their native language than of a second language studied at school or university. Jabak points out some of the underlying reasons for this: "translation into the first language enables translators to render cultural elements such as proverbs, idioms, metaphors, collocations, swear words and others into proper equivalents in their mother tongue because such translators are born and bred in the culture into which they translate these culture-bound aspects. In fact, the translators' first language is naturally acquired in a culture and environment where the first language is naturally acquired and practiced" (Jabak, under "Why is translation into the mother tongue more successful than into a second language?"). Hervey and Higgins emphasize that "translator training normally focuses on translation into the mother tongue, because higher quality is achieved in that direction than in translating into a foreign language" (Hervey and Higgins 2002: 2). Baker (1992) also believes that translators should try to work mostly into their native language, one of her supporting arguments being that foreign language speakers' competence in using idioms almost never equals that of native speakers. Therefore, those who translate into a foreign language can never achieve the sensitivity of a native speaker in judging how and when an idiom should be used. Reiss highlights that "the audience factor is apparent in the common idiomatic expressions, quotations, proverbial allusions and metaphors, etc. of the source language. [...] The translator should make it possible for the reader in the target language to see and understand the text in the terms of his own cultural context" (Reiss 2014: 79). However, because of the increasing market demands for translations, translators often have to translate into a second language. In these circumstances, it becomes even more imperative to concentrate on culture-specific elements in translator training and the different strategies that can be applied in dealing with their translation.

This study aims to discuss some of the relevant factors which might determine the appropriateness and acceptability of the translation of idioms, and to present some of the strategies and frequently used techniques recommended in the specialized literature. We proposed to explore the various solutions which translators - in this case, translator trainees - chose while translating certain idioms from the novel "A Game of Thrones" into Hungarian (their native language). The encountered difficulties and common errors, their strategies and the appropriateness of their choices are analysed and compared with the options of the experienced literary 
translator. The aims of this analysis are the following: to obtain a clearer view of the difficulties they are dealing with, identify their most urgent needs and deficiencies, and bear them in mind when designing teaching materials for translator trainees.

Consequently, the ultimate purpose would be to improve and further develop the quality of translator training by planning and organizing the teaching process, taking into consideration the results of this needs analysis.

\section{The definition and some important features of idioms}

Before exploring the possible strategies regarding the translation of idioms, it is necessary to describe some of those features which can be responsible for the difficulties in their translation. The first problem would be related to their definition. In the Longman dictionary of language teaching and applied linguistics, the term idiom is defined as "an expression which functions as a single unit and whose meaning cannot be worked out from its separate parts. For example: She washed her hands of the matter means She refused to have anything more to do with the matter" (Richards \& Schmidt 2010: 270). A similar definition is given by Seidl and McMordie, who say that "an idiom can be defined as a number of words which, when taken together, have a different meaning from the individual meanings of each word" (Seidl \& McMordie 1988: 12-13). However, according to Brenner, “even many native English speakers aren't clear what constitutes an idiom - they simply use them. [...] Among various dictionary sources, there is some disagreement and confusion about how to define an idiom. [...] One common, basic definition [...] is: two or more words together that, as a unit, have a special meaning that is different from the literal meaning of the words separately" (Brenner 2003: 4-5). These units are not only different in meaning from what the words would mean separately but they are also considered more effective or gripping in certain contexts. As McPherron and Randolph state it, "most linguists, language teachers, language learners, writers, poets, or anyone who has ever thought much about their language will freely admit that idioms provide vivid descriptions and expressions that are more powerful and effective than literal and nonidiomatic language. [...] at the same time, idioms stubbornly resist easy classification and are some of the most difficult vocabulary terms to teach" (McPherron \& Randolph 2014: 1). The difficulty of their classification is also suggested by Kövecses, who compares the linguistic expressions called idioms to a "mixed bag" which "involves metaphors (e.g. spill the beans), metonymies (e.g., throw up one's hands), pairs of words (e.g., cats and dogs), idioms with it (e.g., live it up), similes (e.g., as easy as pie), sayings (e.g., a bird in the hand is worth two in the bush), phrasal verbs (e.g., come up, as in "Christmas is coming up”), grammatical idioms (e.g., let alone), and others” (Kövecses 2010: 231). 
Consequently, an important issue regarding idioms is their classification. If there are different types of idioms, there might be differences regarding the ways they are understood and learned. There have been several attempts to categorize them. For example, Cacciari and Glucksberg (1991) proposed a functional approach based on their degree of compositionality and their semantic transparency. According to the dimension of compositionality, idioms can be noncompositional, partially compositional, and fully compositional.

In noncompositional idioms, no relations between the idiom's constituents and the idiom's meaning can be discerned, as in the idiom cheescake to refer to pinup art [...]. In partially compositional idioms, some relationships between an idiom's constituents and its idiomatic meaning can be discerned and exploited. Although one could not infer the meaning to die from the literal meaning of kick the bucket, the idiom's literal meaning does constrain its use and comprehension. [...] In fully compositional idioms, the constituents map directly onto their idiomatic referents, as in the idiom pop the question (Glucksberg 2001: 73).

According to their degree of transparency - the extent to which the meaning of an idiom can be deduced from the meanings of its constituents -, Glucksberg distinguishes opaque and transparent compositional idioms. "In compositionalopaque idioms, the relations between an idiom's constituents and its meaning may be opaque, but the meanings of individual words can nevertheless constrain both interpretation and use. For the idiom kick the bucket, the semantics of the verb to kick can constrain interpretation. Kicking is a discrete act, and so one could not say he kicked the bucket all week, even though one could say he lay dying all week" (Glucksberg 2001: 74). In the case of compositional-transparent idioms, "there are one-to-one semantic relations between the idiom's constituents and components of the idiom's meaning. In the idiom break the ice, for example, the word break corresponds to the idiomatic sense of abruptly changing an uncomfortable social situation, and the word ice corresponds to the idiomatic sense of social or interpersonal tension" (ibid: 74). Besides noncompositional, compositional-opaque, and compositional-transparent idioms, there is also the quasi-metaphorical type. Such idioms, according to Glucksberg, convey meaning through their allusional content, calling to one's mind prototypes or stereotypes referring to certain situations, actions, or people: "they can simultaneously refer to an ideal exemplar of a concept and characterize some event or situation as an instance of that concept. For the concept doing something prematurely, for example, one might use the metaphorical idiom crossing one's bridges before coming to them" (ibid: 75).

Understanding, learning, and, above all, translating idioms can also be influenced by the different variants and new formats they might appear in. 
Glucksberg (2001) draws attention to the fact that there can be a difference between learning and understanding an idiom, such as spill the beans, and recognizing it as a variant like he didn't spill a single bean. A variant's meaning is not stored and directly available in one's memory; therefore, recognizing variants involves complex mental processing and the implementation of different strategies.

\section{Why are idioms difficult to translate?}

The characteristics of idioms shortly discussed above may in themselves give an explanation for the difficulties which translators have to face while translating them.

English is considered to be a language rich in idioms; therefore, translators should be aware of their nature, types, and usage. An important problem regarding the translation of idioms - in our case, from English into Hungarian - might be their large number in English and the fact that some of them might be difficult to understand even for the native speakers, speaking different varieties of the language, i.e. British, American, Australian, Canadian, or other varieties. The Cambridge international dictionary of idioms (White 1998) explains over 7,000 idioms currently used in British, American, or Australian English. Bárdos (2000) points out that $3,000-4,000$ words constitute the active vocabulary and 4,0005,000 words the passive vocabulary of an advanced learner of a foreign language. If we compare the approximate number of idioms in English to the number of words in the active and passive vocabulary of an advanced learner, it helps us understand the extent of the challenge a translator trainee faces when translating idioms if we consider that his/her command of the second language ideally corresponds to that of an advanced learner's but not to that of a native speaker's.

For a translator, it is not enough to know or recognize an idiom; he/she must also be capable of deciding whether it is acceptable or not to use it in a certain text, depending on its register or genre.

According to Baker, "the main problems that idiomatic and fixed expressions pose in translation relate to two main areas: the ability to recognize and interpret an idiom correctly and the difficulties in rendering various aspects of meaning that an idiom or a fixed expression conveys into the target language" (Baker 1992: 65). She specifies four main difficulties in translating idioms. The first is the lack of an equivalent of an idiom or a fixed expression in the target language. The same meaning can be expressed with a single word in one language and with the help of a fixed expression in another. Therefore, the expectation to find equivalent idioms easily in the target language is unrealistic. Or, some idioms might be culture-specific. In this case, "it is not the specific items an expression contains but rather the meaning it conveys and its association with culture-specific contexts which can make it untranslatable or difficult 
to translate" (ibid: 68). However, as Klaudy emphasizes, translators should be not only linguistic but also cultural mediators and it should be part of their professional competence to know the two cultures and be able to "compare and assess the geographical, historical, social and cultural aspects of two language communities" and develop "strategies to bridge the gaps between different cultures" (Klaudy 2003: 175). The second difficulty enlisted by Baker appears when an idiom has a similar counterpart in the target language, but it is used in different contexts or situations because of its different connotations. The third type of problem occurs when "an idiom may be used in the source text in both its literal and idiomatic senses at the same time. Unless the target-language idiom corresponds to the source-language idiom both in form and in meaning, the play on idiom cannot be successfully reproduced in the target text" (Baker 1992: 69). The fourth difficulty mentioned by Baker is related to the different source-language and target-language conventions regarding the use of idioms in written discourse, certain contexts, or the frequency of their use.

Davies also enlists some problems regarding the translation of idioms and fixed expressions, which show close similarity to the ones defined by Baker: recognition; no equivalent in the target language; a similar counterpart in the target language with a different context of use; an idiom used in the source text both in its literal and idiomatic sense at the same time; difference between the convention, context, and frequency of use in the source and target languages (Davies 2004: 193).

All the above mentioned problems and difficulties may occur in the struggle of the translators to achieve naturalness. As Newmark states it, the level of naturalness achieved in a translation may depend on whether it makes sense, reads naturally, and "is written in ordinary language, the common grammar, idioms and words that meet that kind of situation" (Newmark 1988: 24). Naturalness is important in all text types; this is the main reason why it is almost impossible to produce a proper translation if the translator is not working into his/her language of habitual usage. In order to achieve naturalness, translators should be able to detach themselves mentally from the source-language text and reread and check their work regarding the following: Would they ever see such language usage in texts belonging to the same genre and register written originally in the target language? "Is it usage, is it common usage in that kind of writing? How frequent is it?" (ibid: 26). However, they should not ask themselves whether it is English or not because, according to Newmark, "there is more English than the patriots and the purists and the chauvinists are aware of" (ibid: 26). He also admits that naturalness can be defined easily, "but not so easy to be concrete about. Natural usage comprises a variety of idioms or styles or registers determined primarily by the 'setting' of the text, i.e. where it is typically published or found, secondarily by the author, topic and readership, all of whom are usually dependent on the setting" 
(ibid: 26). When translating idioms, naturalness might also be compromised by the use of books of idioms, dictionaries, which often fail to distinguish "between what is current (e.g. 'keep my head above water') and what is dead (e.g. 'dead as a door nail')", and by the difficulty of matching the equivalence of meaning with the equivalence of frequency (ibid: 28).

It can be concluded that idioms are a challenging domain of translation studies. In order to translate idioms from the source language into the target language, the translator has to choose the most appropriate strategy, taking into consideration their peculiarities, function, culture specificity, semantic and structural unpredictability. When dealing with these difficulties, translators may use various strategies.

\section{Strategies used in the translation of idioms}

According to Baker, the most fortunate and ideal situation would be that they find an idiom with a similar meaning in the target language. However, if they do not, then there are other factors to consider, "for example, the significance of the specific lexical items which constitute the idiom, i.e. whether they are manipulated elsewhere in the source text, as well as the appropriateness or inappropriateness of using idiomatic language in a given register in the target language. The acceptability or non-acceptability of using any of the strategies described below will therefore depend on the context in which a given idiom is translated. [...] Questions of style, register, and rhetorical effect must also be taken into consideration" (Baker 1992: 72).

Baker (1992) enlists five strategies. Some of them will be exemplified here with English-Hungarian translations:

\section{1) Using an idiom of similar meaning and form}

This strategy might seem to be the ideal solution, but other aspects, such as register, style, or rhetorical effect, must be considered as well. Baker agrees with Fernando and Flavell in their warning against the urge that most translators feel to search for an idiom in the target language risking to use even inappropriate ones (Fernando \& Flavell cited in Baker 1992).

Using an idiom of similar meaning and form means to use an idiom in the target language which has approximately the same meaning as the source-language idiom and it contains equivalent lexical items. However, such ideal matches can rarely be achieved.

Examples:

break someone's heart - összetörni valakinek a szívét

face to face - szemtól szembe

step by step - lépésról lépésre 
s/he did not turn a hair - egy hajszála sem görbült meg prepare the ground - elökészíteni a terepet.

\section{2) Using an idiom of similar meaning but dissimilar form}

This strategy is based on the possibility to find an idiom in the target language with a similar meaning to that of the source idiom or expression but containing different lexical items.

Examples:

Jack-of-all-trades - ezermester

one good turn deserves another - jótett helyébe jót várj.

\section{3) Translation by paraphrase}

According to Baker, "this is by far the most common way of translating idioms when a match cannot be found in the target language or when it seems inappropriate to use idiomatic language in the target text because of differences in stylistic preferences of the source and target languages" (ibid: 74).

In order to exemplify this strategy, Baker uses the French translation of the following source text: "One frequent criticism of the Manitoba Government throughout the language controversy was that it never seemed to get a handle on the issue." A possible Hungarian translation using paraphrasing would be: "A nyelvi vita idején egyik gyakori bírálat Manitoba kormányával szemben az volt, hogy a jelek szerint soha nem volt képes kezelni/uralni a helyzetet."

Paraphrasing idioms can also be exemplified with the following EnglishHungarian translation called by Klaudy total transformation (a lexical transfer operation):

He’d cooked Seton's goose all right. - ... Alaposan elintézte Setont.

Although the idiomatic expression to cook sy's goose has some possible corresponding Hungarian idioms (e.g. keresztezi/meghiúsítja valakinek a terveit, ellátja a baját), the translator chose to use a single word (elintéz) (Klaudy 2003: 293-294).

\section{4) Translation by omission}

In certain situations, idioms may be omitted from the target text. The reason for this may be that they cannot be easily paraphrased, they do not have a close match in the target language, or because of stylistic considerations.

\section{5) Strategy of compensation}

This is a strategy which Baker does not try to illustrate because it would take up too much space. "Briefly this means that one may either omit or play down a feature such as idiomaticity at the point where it occurs in the source text and introduce it elsewhere in the target text" (Baker 1992: 78).

As it has been already mentioned before, Klaudy (2003) also deals with the possibilities of translating idioms when describing total transformation. Practically, this lexical transfer operation presented by her may include two of Baker's above mentioned strategies: using an idiom of similar meaning but 
dissimilar form and translation by paraphrase. Some of the examples given by Klaudy (2003: 292-293) are:

várja, hogy a sült galamb a szájába repüljön - to let the grass grow under one’s feet; füt, fát ígér - to promise the moon

falfehéren - white as a sheet.

In Baker's opinion, "using the typical phraseology of the target language - its natural collocations, its own fixed and semi-fixed expressions, the right level of idiomaticity, and so on - will greatly enhance the readability of your translations. Getting this level right means that your target text will feel less 'foreign' and, other factors being equal, may even pass for an original” (Baker 1992: 78).

\section{Analysis of the strategies chosen by the translator trainees}

In this study, we proposed to analyse the various solutions which a group of translator trainees chose while translating into Hungarian twenty idioms (given in context) from the novel "A Game of Thrones” by George R. R. Martin. The students were allowed to use any kind of available resources (online or printed dictionaries), but they did not have access to the official Hungarian translation of the text when working on their translations. Most of them had not read the novel before, but they were familiar with the story because of the popular film adaptation of the book.

The target group consisted of seventeen second-year students studying translation and interpreting (Hungarian and English languages) at Sapientia Hungarian University of Transylvania, Faculty of Technical and Human Sciences Târgu-Mureş. It is important to mention that although a requirement for admission to the Bachelor's programme is to have a B2 level English language certificate and, ideally, they should reach $\mathrm{C} 1$ level by the end of their studies, their translation skills (involving reading comprehension and writing skills) are not always on the appropriate level. Before this task, the group had not received any specific training regarding the issue of how to deal with idioms in translation.

Their strategies and the appropriateness of their choices were examined and compared with the options of the experienced literary translator. However, the sample of the present study is not large enough to draw general conclusions regarding the strategies of translating idioms from English into Hungarian. The aim of this analysis is simply to obtain a clear view of the difficulties the members of the target group are dealing with. It can be considered a needs analysis assessing some of the problems the students may face, and it is only the first part of a more detailed research regarding the design and improvement of teaching materials for translator trainees. 
The following twenty idioms had to be translated: did not rise to the bait, drag him into the quarrel, being made light of, his bowels had turned to water, made his hackles rise, had caught him red-handed, brought up the rear, in the dead of night, an old hand at justice, picked their way carefully, gave her a chill, were taking a toll, a man half in his cups, on wary feet, in a fit of guilt, peas in a pod, in the blink of an eye, guard your tongue, I never asked for this cup to pass to me, coming hard at her heels. They were extracted from the text in the order as they occurred, together with the paragraphs in which they appeared; therefore, they could be interpreted in context. They are of different types and some of them can be regarded as variants of certain idioms.

The students' choices were categorized into acceptable and unacceptable translations and the main strategies chosen by them were also assessed. From Baker's five strategies, four could be identified: (1) using an idiom of approximately similar meaning and form, (2) using an idiom of similar meaning but dissimilar form, (3) translation by paraphrase, and (4) translation by omission. The fourth strategy, translation by omission was not considered acceptable in the case of this task, and they had no reason to apply the fifth strategy (the strategy of compensation) described by Baker. Besides the four previously mentioned strategies, one more could be identified: some students tried to translate certain idioms (5) literally (word-for-word) because they simply did not recognize them as idioms.

In order to illustrate the different strategies chosen by the students, let us examine four examples.

1. Source text: "Gared did not rise to the bait. He was an old man, past fifty, and he had seen the lordlings come and go" (Martin 2011). The meanings of the idiom to rise to the bait given in The Dictionary - Idioms are the following: to respond to an allurement; to fall for an enticement or fall into a trap. The various translations of the idiom did not rise to the bait are shown in Table 1.

As it can be seen in the table, Tamás Pétersz, an experienced translator, who translated the novel into Hungarian with the title Trónok Harca, chose the second strategy - using an idiom of similar meaning but dissimilar form: nem vette fel a kesztyút (Martin 2014). None of the translator trainees used the same Hungarian idiom. However, some of them realized that there is a Hungarian expression related to bait (csali) which can be used as an equivalent of the SL idiom in this context. Some forms of the Hungarian expression used by them are acceptable: nem akadt csalira, nem vette be a csalit, nem harapott a csalira, nem kapta be a csalit, nem harapott rá a csalira, nem ugrott a csalira. They used different verbs, but that does not change the overall meaning of the expression. Two students managed to find and use an idiom of similar meaning but dissimilar form: nem esett bele a csapdába. There were two unacceptable attempts to paraphrase the idiom (nem reagált a cseles kérdéssel, nem 
engedett a fiatal úrfi megjegyzéséhez) and an acceptable one (nem vette fel a piszkálódást). The literal translation nem ment elóre a csalihoz is unacceptable.

\section{Table 1.}

\begin{tabular}{|c|c|c|c|c|c|c|}
\hline $\begin{array}{c}\text { SL } \\
\text { (EN) }\end{array}$ & $\begin{array}{c}\text { TL } \\
\text { (HU) }\end{array}$ & $\begin{array}{c}\begin{array}{c}\text { Student's } \\
\text { initials }\end{array} \\
\end{array}$ & Student's translation & $\begin{array}{l}\text { Strategy } \\
(\mathbf{1} / \mathbf{2} / \mathbf{3} / \mathbf{4} / \mathbf{5}) \\
\end{array}$ & $\begin{array}{l}\text { Acceptable } \\
\text { translation }\end{array}$ & $\begin{array}{c}\text { Unacceptable } \\
\text { translation }\end{array}$ \\
\hline \multirow{18}{*}{ 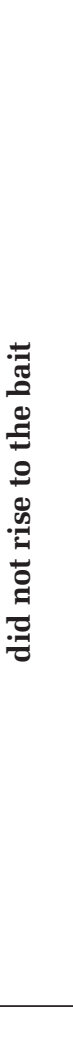 } & \multirow{18}{*}{ 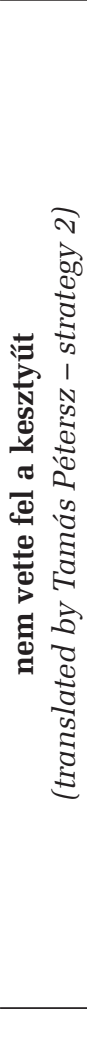 } & $\mathrm{CR}$ & $\begin{array}{l}\text { nem reagált a cseles } \\
\text { kérdéssel }\end{array}$ & 3 & & $\mathrm{x}$ \\
\hline & & DI & $\begin{array}{l}\text { nem vette fel a } \\
\text { piszkálódást }\end{array}$ & 3 & $\mathrm{x}$ & \\
\hline & & FI & nem akadt csalira & 1 & $\mathrm{x}$ & \\
\hline & & IE & $\begin{array}{l}\text { nem ment elóre a } \\
\text { csalihoz }\end{array}$ & 5 & & $\mathrm{x}$ \\
\hline & & IB & nem vette be a csalit & 1 & $\mathrm{x}$ & \\
\hline & & KB & nem harapott a csalira & 1 & $\mathrm{x}$ & \\
\hline & & $\mathrm{KN}$ & $\begin{array}{l}\text { nem vette számba a } \\
\text { csalit }\end{array}$ & 3 & & $\mathrm{x}$ \\
\hline & & $\mathrm{KV}$ & nem kapta be a csalit & 1 & $\mathrm{x}$ & \\
\hline & & KK & nem kapta be a csalit & 1 & $\mathrm{x}$ & \\
\hline & & KA & nem vette be a csalit & 1 & $\mathrm{x}$ & \\
\hline & & $\mathrm{ME}$ & $\begin{array}{l}\text { nem harapott rá a } \\
\text { csalira }\end{array}$ & 1 & $\mathrm{x}$ & \\
\hline & & $\mathrm{PH}$ & nem ugrott a csalira & 1 & $\mathrm{x}$ & \\
\hline & & SZs & $\begin{array}{l}\text { nem engedett a fiatal } \\
\text { úrfi megjegyzéséhez }\end{array}$ & 3 & & $\mathrm{x}$ \\
\hline & & SzA & $\begin{array}{l}\text { nem esett bele a } \\
\text { csapdába }\end{array}$ & 2 & $\mathrm{x}$ & \\
\hline & & SzZs & $\begin{array}{l}\text { nem esett bele a } \\
\text { csapdába }\end{array}$ & 2 & $\mathrm{x}$ & \\
\hline & & SzS & nem akadt a csalira & 1 & $\mathrm{x}$ & \\
\hline & & $\mathrm{VN}$ & nem vette be a csalit & 1 & $\mathrm{x}$ & \\
\hline & & & Total & & 13 & 4 \\
\hline
\end{tabular}

2. Source text: "Will had known they would drag him into the quarrel sooner or later. He wished it had been later rather than sooner" (Martin 2011). The meaning of the idiom to drag (someone) into (something) given in The Free Dictionary - Idioms is the following: to force, impel, involve, or convince someone to participate in an undesirable situation or action. The various translations of the idiom drag him into the quarrel are shown in Table 2. 
Table 2.

\begin{tabular}{|c|c|c|c|c|c|c|}
\hline $\begin{array}{c}\text { SL } \\
\text { (EN) }\end{array}$ & $\begin{array}{c}\text { TL } \\
\text { (HU) }\end{array}$ & $\begin{array}{c}\text { Student's } \\
\text { initials }\end{array}$ & Student's translation & $\begin{array}{c}\text { Strategy } \\
(1 / 2 / 3 / 4 / 5)\end{array}$ & $\begin{array}{l}\text { Acceptable } \\
\text { translation }\end{array}$ & $\begin{array}{c}\text { Unacceptable } \\
\text { translation }\end{array}$ \\
\hline \multirow{17}{*}{ 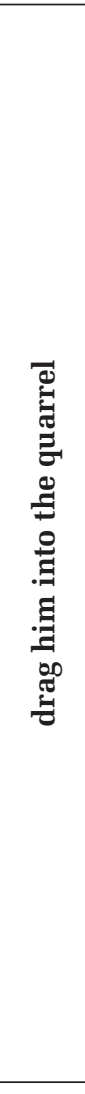 } & \multirow{17}{*}{ 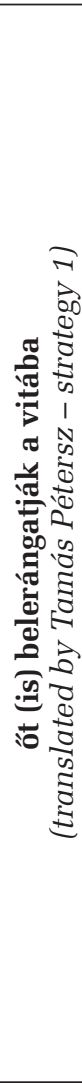 } & CR & veszekedés lesz & 3 & $\mathrm{x}$ & \\
\hline & & DI & $\begin{array}{l}\text { ôt is belerángatják a } \\
\text { vitába }\end{array}$ & 1 & $\mathrm{x}$ & \\
\hline & & FI & $\begin{array}{l}\text { őt is belesodorják a } \\
\text { vitába }\end{array}$ & 2 & $\mathrm{x}$ & \\
\hline & & $\mathrm{IE}$ & $\begin{array}{l}\text { bele fogják ôt vonni a } \\
\text { vitába }\end{array}$ & 5 & & $\mathrm{x}$ \\
\hline & & IB & $\begin{array}{l}\text { belekeverik a } \\
\text { veszekedésbe }\end{array}$ & 2 & $\mathrm{x}$ & \\
\hline & & KB & vitába fog keveredni & 2 & $\mathrm{x}$ & \\
\hline & & $\mathrm{KN}$ & $\begin{array}{l}\text { belerángatják a } \\
\text { civakodásba }\end{array}$ & 1 & $\mathrm{x}$ & \\
\hline & & KV & veszekedés lesz & 3 & $\mathrm{x}$ & \\
\hline & & KK & belekeveredik a vitába & 2 & $\mathrm{x}$ & \\
\hline & & KA & $\begin{array}{l}\text { a veszekedésbe húzzák } \\
\text { ôt }\end{array}$ & 5 & & $\mathrm{x}$ \\
\hline & & $\mathrm{ME}$ & vitába keverednek & 2 & $\mathrm{x}$ & \\
\hline & & $\mathrm{PH}$ & $\begin{array}{l}\text { ôt is bevonják a } \\
\text { veszekedésbe }\end{array}$ & 3 & & $\mathrm{x}$ \\
\hline & & $\mathrm{SZs}$ & $\begin{array}{l}\text { belekeverik ót is a } \\
\text { vitába }\end{array}$ & 2 & $\mathrm{x}$ & \\
\hline & & SzA & belekeverik a vitába & 2 & $\mathrm{x}$ & \\
\hline & & $\mathrm{SzZs}$ & belekeverik a vitába & 2 & $\mathrm{x}$ & \\
\hline & & $\mathrm{SzS}$ & $\begin{array}{l}\text { behúzzák ôt is a } \\
\text { veszekedésbe }\end{array}$ & 5 & & $\mathrm{x}$ \\
\hline & & $\mathrm{VN}$ & $\begin{array}{l}\text { a veszekedésbe húzzák } \\
\text { ôt }\end{array}$ & 5 & & $\mathrm{x}$ \\
\hline & & & Total & & 12 & 5 \\
\hline
\end{tabular}

In this case, Tamás Pétersz chose the first strategy - using an idiom of approximately similar meaning and similar form: ót (is) belerángatják a vitába (Martin 2014). Two students also realized that in Hungarian there is a similar expression (belerángatni valakit valamibe), and used it in their translations: ôt is belerángatják a vitába, belerángatják a civakodásba. Five students used an idioms of similar meaning but slightly dissimilar form: belekeverik a veszekedésbe, belekever(ed)ik (ót is) a vitába, vitába keverednek. Others used translation by paraphrase: veszekedés lesz. Four attempts of literal translation and one to paraphrase the idiom proved unacceptable.

3. Source text: "Gared had spent forty years in the Night's Watch, man and boy, and he was not accustomed to being made light of" (Martin 2011). The 
meaning of the idiom to make light of given in The Free Dictionary - Idioms is the following: to treat something as if it were unimportant or humorous. The various translations of the idiom from the text are shown in Table 3.

Table 3.

\begin{tabular}{|c|c|c|c|c|c|c|}
\hline $\begin{array}{l}\text { SL } \\
\text { (EN) }\end{array}$ & $\begin{array}{c}\text { TL } \\
\text { (HU) }\end{array}$ & $\begin{array}{c}\text { Student's } \\
\text { initials }\end{array}$ & Student's translation & $\begin{array}{c}\text { Strategy } \\
(1 / 2 / 3 / 4 / 5)\end{array}$ & $\begin{array}{l}\text { Acceptable } \\
\text { translation }\end{array}$ & $\begin{array}{c}\text { Unacceptable } \\
\text { translation }\end{array}$ \\
\hline \multirow{18}{*}{ 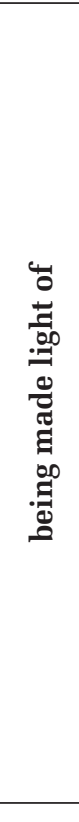 } & \multirow{17}{*}{ 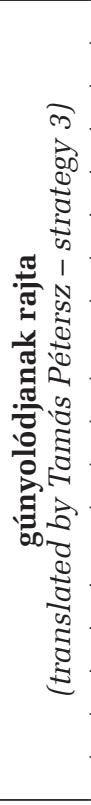 } & CR & gúnyolódjanak rajta & 3 & $\mathrm{x}$ & \\
\hline & & DI & gúnyolódjanak rajta & 3 & $\mathrm{x}$ & \\
\hline & & FI & gúnyolódjanak vele & 3 & $\mathrm{x}$ & \\
\hline & & IE & félvállról vegyék & 2 & $\mathrm{x}$ & \\
\hline & & IB & kigúnyolják őt & 3 & $\mathrm{x}$ & \\
\hline & & $\mathrm{KB}$ & aki a düh embere & 3 & & $\mathrm{x}$ \\
\hline & & KN & félvállról vegyék & 2 & $\mathrm{x}$ & \\
\hline & & KV & $\begin{array}{l}\text { figyelmen kívül } \\
\text { hagyják }\end{array}$ & 3 & $x$ & \\
\hline & & KK & félvállról vegyék & 2 & $\mathrm{x}$ & \\
\hline & & KA & - & 4 & & $\mathrm{x}$ \\
\hline & & $\mathrm{ME}$ & figyelmen kívül hagyja & 3 & & $\mathrm{x}$ \\
\hline & & $\mathrm{PH}$ & $\begin{array}{l}\text { viccet csináljanak } \\
\text { belőle }\end{array}$ & 3 & $\mathrm{x}$ & \\
\hline & & SZs & nem veszik komolyan & 3 & $\mathrm{x}$ & \\
\hline & & SzA & erre rávilágítsanak & 3 & & $\mathrm{x}$ \\
\hline & & SzZs & erre rávilágítsanak & 3 & & $\mathrm{x}$ \\
\hline & & $\mathrm{SzS}$ & csúfot ûzzenek belőle & 2 & $\mathrm{x}$ & \\
\hline & & $\mathrm{VN}$ & - & 4 & & $\mathrm{x}$ \\
\hline & & & Total & & 11 & 6 \\
\hline
\end{tabular}

Here, Tamás Pétersz used the third strategy - he paraphrased the idiom: gúnyolódjanak rajta (Martin 2014). Three students also chose the verb gúnyolódni/ kigúnyolni (taunt/mock/ridicule) to paraphrase the idiom. Other acceptable attempts to paraphrase the idiom were the following: viccet csináljanak belóle, nem veszik komolyan. There were three successful attempts to use expressions of similar meaning but dissimilar form: félvállról vegyék, csúfot üzzenek belóle, figyelmen kívül hagyják. Four of the paraphrasing attempts and the two omissions were unacceptable.

4. Source text: "Will had been a hunter before he joined the Night's Watch. Well, a poacher in truth. Mallister freeriders had caught him red-handed in the Mallisters' own woods, skinning one of the Mallisters' own bucks, and it had been a choice of putting on the black or losing a hand" (Martin 2011). The meaning of the idiom to catch someone red-handed given in The Free Dictionary - Idioms is 
the following: to catch a person in the act of doing something wrong. The various translations of the idiom from the text are shown in Table 4.

Table 4.

\begin{tabular}{|c|c|c|c|c|c|c|}
\hline $\begin{array}{c}\text { SL } \\
\text { (EN) }\end{array}$ & $\begin{array}{c}\text { TL } \\
\text { (HU) }\end{array}$ & $\begin{array}{c}\text { Student's } \\
\text { initials }\end{array}$ & Student's translation & $\begin{array}{c}\text { Strategy } \\
(1 / 2 / 3 / 4 / 5)\end{array}$ & $\begin{array}{l}\text { Acceptable } \\
\text { translation }\end{array}$ & $\begin{array}{c}\text { Unacceptable } \\
\text { translation }\end{array}$ \\
\hline \multirow{18}{*}{ 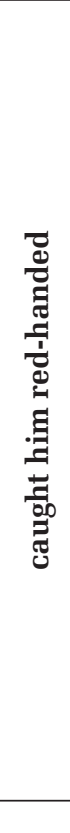 } & \multirow{18}{*}{ 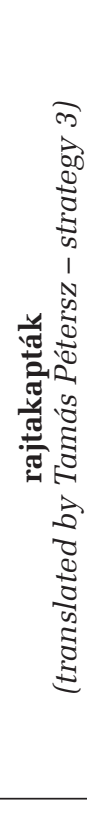 } & CR & $\begin{array}{l}\text { ót elkaptak mikor tett } \\
\text { ér }\end{array}$ & 3 & & $\mathrm{x}$ \\
\hline & & DI & tetten érték ôt & 2 & $\mathrm{x}$ & \\
\hline & & FI & fülön csípték & 2 & $\mathrm{x}$ & \\
\hline & & IE & tetten érték & 2 & $\mathrm{x}$ & \\
\hline & & IB & elkapták véres kézzel & 5 & & $\mathrm{x}$ \\
\hline & & $\mathrm{KB}$ & véreskezúnek találták & 5 & & $\mathrm{x}$ \\
\hline & & $\mathrm{KN}$ & rajtakapták & 3 & $\mathrm{x}$ & \\
\hline & & $\mathrm{KV}$ & - & & & $\mathrm{x}$ \\
\hline & & KK & $\begin{array}{l}\text { szélhámosságon } \\
\text { kapták }\end{array}$ & 3 & $\mathrm{x}$ & \\
\hline & & KA & - & & & $\mathrm{x}$ \\
\hline & & $\mathrm{ME}$ & tetten érték & 2 & $\mathrm{x}$ & \\
\hline & & $\mathrm{PH}$ & - & & & $\mathrm{x}$ \\
\hline & & SZs & tetten érték & 2 & $\mathrm{x}$ & \\
\hline & & SzA & elkapták/tetten érték & 2 & $\mathrm{x}$ & \\
\hline & & SzZs & tetten érték & 2 & $\mathrm{x}$ & \\
\hline & & SzS & rátaláltak & 3 & $\mathrm{x}$ & \\
\hline & & VN & - & & & $\mathrm{x}$ \\
\hline & & & Total & & 10 & 7 \\
\hline
\end{tabular}

In this case, Pétersz used the third strategy again; he paraphrased the idiom, using only one word: rajtakapták (Martin 2014). Seven students successfully managed to find Hungarian expressions with similar meaning but dissimilar form: tetten érték, fülön csípték. There were three successful paraphrasing attempts (rátaláltak, szélhámosságon kapták, rajtakapták). One paraphrasing, two wordfor-word translation attempts, and four omissions were unacceptable.

Regarding the acceptability of the translations of the twenty given idioms, $61 \%$ proved to be acceptable and $39 \%$ unacceptable, as it is shown in the diagram.

The main reasons for unacceptability were the following: not recognizing the fact that the respective phrase is an idiom, problems with interpretation, use of inappropriate style and incorrect grammatical structures. However, these reasons were not necessarily related to the choice of strategy (except those who omitted the idiom or tried to translate them literally because they failed to recognize them as idioms). 


\section{The acceptability of the translations}

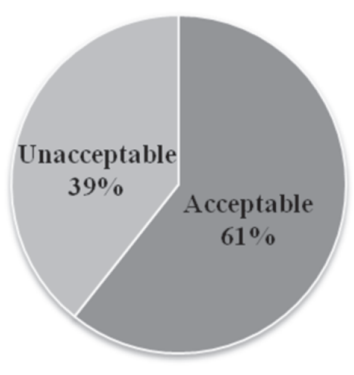

The frequency of use of the different strategies can be seen in the following diagram:

\section{Strategies used by the translator trainees}

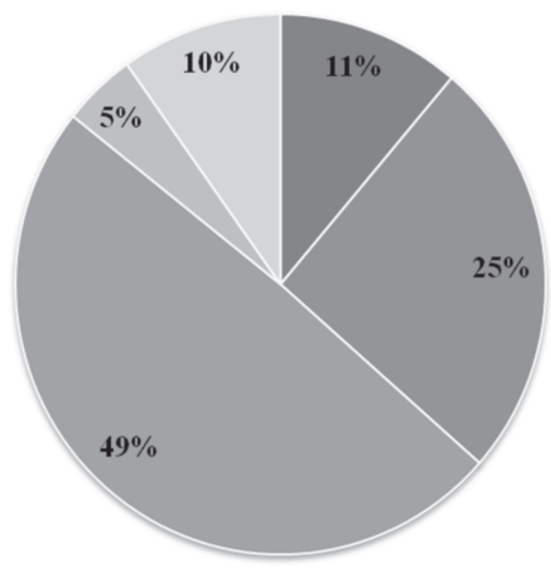

(1) using an idiom of approximately similar meaning and form

m(2) using an idiom of similar meaning but dissimilar form

m(3) translation by paraphrase

(4) translation by omission

(5) literal (word-for-word) translation

The most frequently chosen strategy was translation by paraphrase. This confirms Baker's opinion, who also concluded that this is the most commonly used strategy. The strategy of paraphrasing was followed in frequency by the attempt of using an idiom of similar meaning but dissimilar form. Some of the idioms proved to have an equivalent of approximately similar meaning and form in the target language, and in most cases this was recognized by the students. Translations by omission were not considered acceptable and very few literal translations proved to be appropriate. The translator trainees' choice of strategy is not very different from that of the experienced translator (Tamás Pétersz) regarding the order of frequency and the percentage of strategies. Pétersz used translation by paraphrase in 55\%, an idiom of similar meaning but dissimilar form in $30 \%$, and an idiom of approximately similar meaning and form in $15 \%$. 


\section{Conclusions}

The aim of this study was to obtain a clear view of the difficulties and problems that a group of translator trainees may encounter in translating idioms. It can be considered a needs analysis because assessing some of the problems they face can help us design more appropriate teaching materials for them. However, as we have mentioned it before, the sample of the present study is not large enough to draw general conclusions regarding the strategies of translating idioms from English into Hungarian.

Based on the analysis of the strategies used by the translator trainees and the appropriateness of their choices, it can be concluded that it is a major challenge for them to translate idioms. The analysis has shown that their translations involved five main strategies: (1) using an idiom of approximately similar meaning and form, (2) using an idiom of similar meaning but dissimilar form, (3) translation by paraphrase, (4) translation by omission, and (5) literal (word-forword) translation. Although they worked with the idioms instinctively, without any previous training regarding this particular domain, the most frequently used strategy was translation by paraphrase, which confirmed the information relating to the predominant frequency of this strategy presented in other studies.

The fact that $39 \%$ of their options were not acceptable due to the non-recognition of certain idioms, problems with interpretation, use of inappropriate style, and incorrect grammatical structures, draws our attention to the need to introduce the issue of translating idioms into the training programme, including idiom-typology, possible problems of recognition and interpretation, and translation strategies.

Therefore, a further step in our work will be to introduce the topic of the translation of idioms into the curriculum and design appropriate materials to develop our students' knowledge and skills in this domain. In order to increase their awareness regarding the translation of idioms, we intend to introduce specific activities and tasks, such as: the presentation, explanation, discussion, exemplification, and practice of idiom recognition and the strategies of idiom translation; comparative analysis of translated texts where the source-language texts are rich in idioms; vocabulary activities focused on idioms; creation of glossaries containing idioms, their explanations, and their possible translations into Hungarian; translating texts rich in idioms; search for online dictionaries and resources that make the translation of idioms easier.

Obviously, the translation of idioms becomes easier with a deeper knowledge of the languages and cultures the translators are working with. But, if they become aware of the issues regarding the different types of idioms, the importance of their recognition, and their appropriate interpretation, this may help them in facing the challenge of translating them. 


\section{References}

Baker, Mona. 1992. In other words: a coursebook on translation. London and New York: Routledge.

Bárdos, Jenő. 2000. Az idegen nyelvek tanításának elméleti alapjai és gyakorlata [The theory and practice of foreign language teaching]. Budapest: Nemzeti Tankönyvkiadó.

Brenner, Gail. 2003. Webster's new world American idioms handbook. Indianapolis: Wiley Publishing, Inc.

Cacciari, Cristina-Glucksberg, Sam. 1991. Understanding idiomatic expressions: the contribution of word meanings. In: Simpson, Greg B. (ed.), Understanding word and sentence. North-Holland: Elsevier Science Publishers.

Davies, Maria Gonzales. 2004. Multiple voices in the translation classroom: activities, tasks and projects. Amsterdam and Philadelphia: John Benjamins.

Glucksberg, Sam. 2001. Understanding figurative language: from metaphor to idioms. Oxford University Press.

Hervey, Sándor-Higgins, Ian. 2002 [1992]. Thinking French translation. London and New York: Routledge.

Jabak, Omar. Why is translation into the mother tongue more successful than into a second language? http://www.translationdirectory.com/articles/article1508. php (accessed on: 4 March 2016).

Klaudy, Kinga. 2003 [1994]. Languages in translation. Budapest: Scholastica.

Kövecses, Zoltán. 2010. Metaphor: a practical introduction. Oxford: Oxford University Press.

Martin, George R. R. 2011 [1996]. A game of thrones. London: Harper Voyager.

Martin, George R. R. 2014. Trónok harca [A game of thrones]. Translated by Tamás Pétersz. Budapest: Alexandra.

Seidl, Jennifer-Mc Mordie, William. 1988 [1978]. English idioms (5 ${ }^{\text {th }}$ edition). Oxford; New York: Oxford University Press.

McPherron, Paul-Randolph, Patrick T. 2014. Cat got your tongue?: Recent research and classroom practices for teaching idioms to English learners around the world. TESOL Press.

Newmark, Peter. 1988. A textbook on translation. New York, London: Prentice Hall.

Reiss, Katharina. 2014 [2000]. Translation criticism - potentials and limitations. London and New York: Routledge.

Richards, Jack C.-Schmidt, Richard W. 2010 [1985]. Longman dictionary of language teaching and applied linguistics. London: Pearson.

White, James Gordon. 1998. The Cambridge international dictionary of idioms. Cambridge: Cambridge University Press. 